\title{
Evaluasi Terapi Antibiotik Empirik Terhadap Clinical Outcome pada Pasien Anak Dengan Meningitis Bakteri di Bangsal Rawat Inap RSUP Dr. Sardjito Yogyakarta 2010- 2015
}

Evaluation of Empiric Antibiotic Therapy Toward Clinical Outcome in Children Patients with Bacterial Meningitis in Dr. Sardjito General Hospital Yogyakarta 2010-2015

\section{Wihda Yanuar'1, Ika Puspita Sari2 ${ }^{*}$, Titik Nuryastuti ${ }^{3}$}

1. Magister Farmasi Klinik, Fakultas Farmasi, UGM

2. Departemen Farmakologi \& Farmasi Klinik, Fakultas Farmasi, UGM

3. Departemen Mikrobiologi, Fakultas Kedokteran, Kesehatan Masyarakat dan Keperawatan, UGM

Corresponding author: Ika Puspita Sari: Email: ika.puspitasari@gmail.com

\begin{abstract}
ABSTRAK
Kasus meningitis bakteri di Indonesia mencapai 158/100,000. Meningitis bacterial menyerang anak usia kurang dari 2 tahun. Pasien dengan meningitis bakteri yang bertahan hidup beresiko mengalami komplikasi berupa kerusakan otak. Oleh karena itu, pasien meningitis bakterial khususnya pada anak perlu mendapatkan terapi yang optimal. Penelitian ini bertujuan untuk mengetahui pola penggunaan antibiotik empirik terhadap cinical outcome pasien anak dengan meningitis bakteri di bangsal rawat inap RSUP Dr. Sardjito Yogyakarta. Penelitian dilakukan dengan rancangan deskriptif observasional dengan pengumpulan data secara retrospektif terhadap rekam medis pasien yang memenuhi kriteria inklusi. Didapat sebanyak 25 pasien yang sesuai criteria inklusi. Hasil penelitian menunjukkan bahwa penggunaan antibiotik empirik $26 \%$ sesuai dengan guideline terapi meningitis bacteri. Clinical outcome penggunaan antibiotik empiric yang mengalami perbaikan sebesar $40 \%$.
\end{abstract}

Kata kunci : antibiotic empiric, clinical outcome, meningitis bakteri

\begin{abstract}
Cases of bacterial meningitis in Indonesia reach 158/100,000. Bacterial meningitis attacks children less than 2 years old. Patients with bacterial meningitis who survive are at risk for complications such as brain damage. Therefore, patients with bacterial meningitis, especially in children, need to get optimal therapy. This study aims to determine the pattern of empirical antibiotic use on clinical outcome of pediatric patients with bacterial meningitis in the inpatient ward of Sardjito General Hospital. The study was conducted in an observational descriptive design by collecting data retrospectively on the medical records of patients who met the inclusion criteria. There were 25 patients who met the inclusion criteria. The results showed that $26 \%$ use of empiric antibiotics was in accordance with the guidelines for the treatment of bacterial meningitis. Empiric therapy increased clinical outcomes of $40 \%$ patients.
\end{abstract}

Keyword: empiric therapy, clinical outcome, bacterial meningitis 


\section{PENDAHULUAN}

Kasus meningitis bakteri di Indonesia mencapai 158/100,000 kasus pertahun, dengan etiologi Haemophilus influenza tipe b (H. influenza) 16/100.000 dan bakteri lain 67/100.000 (Alam, 2011). pasien meningitis bakteri khususnya pada anak perlu mendapatkan terapi yang optimal mengingat pasien dapat mengalami komplikasi berupa kerusakan pada otak (Prasad dkk., 2007). Ketersediaan antibiotik saat ini telah terjamin, namun meningitis bakteri tetap memiliki angka morbiditas dan mortalitas yang tinggi. Angka mortalitas pada pasien yang diobati adalah sekitar $10 \%$ dari jumlah kasus yang dilaporkan. Angka kematian pada kasus yang tidak diobati adalah 50-90\% (Japardi, 2002). Persentase angka mortalitas dan morbiditas yang cukup tinggi pada kasus meningitis bacteri sehingga diperlukan terapi yang tepat dan efektif untuk pasien. Ketepatan terapi antibiotic untuk meningitis bakteri sangat menentukan outcome terapi pasien. Penelitian ini dimaksudkan untuk mengevaluasi ketepatan antibiotic untuk terapi empiric pada kasus meningitis bakteri dengan mempertimbangkan farmakokinetika dan farmakodinamik antibiotic.

\section{METODOLOGI}

$\begin{array}{llr}\text { Penelitian } & \text { ini } & \text { menggunakan } \\ \text { rancangan penelitian } & \text { diskriptif }\end{array}$ observasional dengan desain retrospektif untuk melakukan evaluasi penggunaan antibiotic empiric serta clinical outcome pasien. Pengumpulan data dilakukan secara retrospektif terhadap rekam medis pasien anak dengan diagnosa meningitis bakteri di bangsal rawat inap RSUP Dr. Sardjito Yogyakarta periode 1 Januari 2010 sampai 31 Desember 2015. Pasien yang memenuhi kriteria inklusi sebanyak 25 pasien dievaluasi ketepatan antibiotiknya.

Analisa data dilakukan deskriptif dilakukan terhadap demografi pasien (umur dan jenis kelamin) dan penyakit penyerta. Gambaran ketepatan antibiotik empirik terhadap clinical outcome dianalisis secara deskriptif.

\section{Jalannya penelitian}

Kriteria inklusi yaitu pasien anak usia 1 bulan - 18 tahun yang didiagnosis meningitis bakteri dan mendapat terapi antibiotic.

\section{HASIL DAN PEMBAHASAN}

Pasien meningitis bakteri lebih banyak diderita anak umur 1 bulan hingga 2 tahun $(63,3 \%)$ dan lebih banyak pasien laki-laki (Tabel I). Penyakit penyerta infeksi dan non infeksi sama banyaknya.

Jenis antibiotic yang diberikan untuk meningitis berupa antibiotic kombinasi lebih banyak yaitu $44 \%$ (Table II).

Kombinasi ampisilin dan kloramfenikol (26\%) menjadi pilihan terbanyak untuk terapi empirik di RSUP Dr. Sardjito. Tidak ada perbedaan clinical outcome untuk meningitis bakteri anak pada penggunaan kloramfenikol dengan ampisillin secara tunggal maupun kombinasi (Prasad dkk., 2007). Penggunaan kombinasi kloramfenikol+ampisillin memiliki efikasi yang sama dengan penggunaan sefotaksim dan seftriakson (Prasad dkk., 2007). Namun dalam penelitian ini pemberian antibiotic empiric dengan ampisilin dan kloramfenikol tidak semua mengalami perbaikan kondisi. Sefotaksim digunakan untuk meningitis bakteri karena Staphylococcus, Streptococcus dan E.coli. Menurut International Society of Neurosurgery tahun 2016, sefotaksim merupakan antibotik yang menjadi pilihan untuk meningitis bakteri pada anak yang disebabkan E. coli. Bakteri E. coli merupakan bakteri Gram negatif yang paling sering menjadi penyebab meningitis bakteri anak di Amerika Serikat. Sefotaksim merupakan antibiotik yang memiliki spektrum luas dan memiliki aktivitas penetrasi yang bagus untuk menembus BBB meskipun dalam keadaan inflamasi (Brouwer etal., 2010). Sefotaksim juga merupakan antibiotik yang 
Tabel I. Karakteristik umur pasien meningitis bakteri anak di RSUP Dr. Sardjito tahun 2010-2015

\begin{tabular}{lcc}
\hline & Jumlah pasien & Persentase (\%) \\
\hline Umur & & \\
$\quad \begin{array}{l}\text { 1 bulan }-<2 \text { tahun } \\
2 \text { tahun }-<18 \text { tahun }\end{array}$ & 14 & 63,3 \\
$\begin{array}{l}\text { Jenis kelamin } \\
\quad \text { Laki-laki }\end{array}$ & 11 & 36,7 \\
$\quad \begin{array}{l}\text { Perempuan } \\
\text { Penyakit penyerta }\end{array}$ & 12 & 56,7 \\
$\quad \begin{array}{l}\text { Infeksi (HAP, TB, diare, ISK, selulitis, ISPA) } \\
\quad \text { Non infeksi (anemia, malnutrisi, epilepsy, } \\
\text { hiponatremia, tifoid) }\end{array}$ & 14 & 43,3 \\
\hline
\end{tabular}

Tabel II. Gambaran antibiotik empiris pada meningitis bakteri anak di RSUP Dr. Sardjito tahun 2010-2015.

\begin{tabular}{lcc}
\hline Nama Antibiotik & Jumlah kasus & Persentase (\%) \\
\hline Ampisillin+Kloramfenikol (AMP+CHL) & 9 & 26.00 \\
Ampisillin+Gentamisin (AMP+GEN) & 2 & 6.00 \\
Sefotaksim + Siprofloksasin (CTX+CIP) & 1 & 3.00 \\
Sefotaksim (CTX) & 8 & 24.00 \\
Seftriakson (CRO) & 6 & 18.00 \\
Ampisillin (AMP) & 4 & 12.00 \\
Seftazidim (CAZ) & 2 & 6.00 \\
Meropenem (MEM) & 1 & 3.00 \\
Gentamisin (GEN) & 1 & 3.00 \\
n= regimen penggunaan antibiotik & $\mathbf{3 4}$ & $\mathbf{1 0 0 . 0 0}$ \\
\hline
\end{tabular}

direkomendasikanuntuk meningitis bakteri anak yang disebabkan karena bakteri Gram positif maupun Gram negatif (Tunkel dkk., 2004). Review yang dilakukan oleh WHO pada tahun 2008 menyebutkan bahwa penelitian yang telah dilakukan oleh Martin dkk, dan Singi dkk, tentang pemberian seftriakson pada pasien anak dengan meningitis bakterial, clinical outcome pasien meningitis bakterial terlihat setelah 7-10 hari pemberian seftriakson.

Antibiotik golongan fluorokuinolon yang efektif digunakan untuk meningitis bakterial anak adalah siprofloksasin dan levofloksasin. Siprofloksasin dan levofloksasin merupkan antibotik golongan fluorokuinolon generasi II yang memiliki spektrum luas, memiliki kemampuan untuk melawan bakteri Gram positif maupun Gram negatif, yang memiliki kemampuan untuk penetrasi ke sistem syaraf pusat dengan baik, sehingga dapat digunakan sebagai terapi untuk meningitis bakteri, namun sebaiknya penggunaannya disesuaikan dengan hasil uji kultur dan sensitivitas antibotik (Goldman dan Kearns, 2011).

Antibiotik golongan aminoglikosida seperti amikasin dan gentamisin merupakan antibotik spektrum luas yang efektif untuk bakteri Gram negatif, tetapi pemberiannya untuk meningitis bakteri sebaiknya diberikan secara kombinasi karena kemampuan untuk penetrasi ke CNS kurang bagus (El Bashir dkk., 2003).

Berdasarkan review yng dilakukan oleh WHO pada tahun 2008 menyebutkan bahwa meropenem memiliki kemampuan untuk melawan bakteri Gram negatif. Penelitian yang telah dilakukan di Namibia 
Tabel III. Ketepatan regimen antibiotik empiris pada meningitis bakteri anak di RSUP Dr. Sardjito tahun 2010-2015

\begin{tabular}{lllll}
\hline Antibiotik & \multicolumn{1}{c}{$\begin{array}{c}\text { Dosis } \\
\text { guidelline }\end{array}$} & $\begin{array}{c}\text { Dosis yang } \\
\text { diberikan (min- } \\
\text { mak) }\end{array}$ & \multicolumn{1}{c}{ Frekuensi } & $\begin{array}{c}\text { Durasi } \\
\text { (hari) }\end{array}$ \\
\hline AMP+CHL & $200+100$ & $100-200 \&$ 70-128 & Per 6 jam; per 8 jam; per 12 jam & $2-3$ \\
AMP+GEN & $200+5$ & $103-105 \& 5,2-8,4$ & GEN per 12 jam & $4-12$ \\
CTX+CIP & $200+10$ & $97,5+29,3$ & Per 8 jam & 8 \\
CTX & 200 & $62,5-259$ & Per 6 jam; per 8 jam & $3-15$ \\
CRO & 100 & $54-100$ & Per 12 jam & $7-21$ \\
AMP & 200 & $103-218$ & Per 6 jam; per 8 jam; per 12 jam & $5-11$ \\
CAZ & 50 & 25 & Per 8 jam & 11 \\
MEM & $20-40$ & 60 & Per 8 jam & 7 \\
GEN & 5 & 5,2 & Per 12 jam & 3 \\
Antibiotik yang sesuai dosis, frekuensi dan durasi: $\mathbf{9 ( 2 6 \% )}$ & \\
\hline
\end{tabular}

Tabel IV. Gambaran clinical outcome meningitis bakteri anak di RSUP Dr. Sardjito tahun 2010-2015.

\begin{tabular}{lcc}
\hline & Membaik & Memburuk \\
\hline Antibiotik empirik & $10(40 \%)$ & $15(60 \%)$ \\
& AMP+CHL (4); CTX (6) & Lanjut terapi definitif \\
\hline
\end{tabular}

pada tahun 2009-2012 dengan menggunakan isolat LCS diperoleh hasil penelitian bahwa ditemukan kejadian ESBL yang disebabkan oleh $K$. pneumonia dan $E$. coli, antibiotik golongan carbapenem (meropenem) memiliki sensitivitas baik dan dapat direkomendasikan sebagai terapi empiris untuk pasien yang diduga ESBL, sedangkan meningitis karena $K$. pneumonia bukan ESBL direkomendasikan untuk menggunakan kombinasi antibotik golongan sefalosporin dengan golongan aminoglikosida (Mengistu dkk., 2013). Bakteri $K$. pneumonia telah dicurigai sebagai penyebab infeksi nosokomial. ESBL karena Klebsiella telah menjadi masalah besar di rumah sakit karena resistensinya terhadap beberapa antibiotik (Mengistu dkk., 2013).

\section{KESIMPULAN}

Sebanyak $26 \%$ pasien mendapat terapi antibiotic yang tepat, dan outcome pasien mengalami perbaikan sebanyak $40 \%$.

\section{UCAPAN TERIMA KASIH}

Penulis mengucapkan terimakasih kepada Fakultas Kedokteran UGM yang telah memberikan bantuan dana melalui Hibah Dana Masyarakat, Fakultas Kedokteran UGM Tahun 2012.

\section{DAFTAR PUSTAKA}

Alam, A., 2011. Kejadian Meningitis Bakterial pada Anak usia 6-18 bulan yang

Menderita Kejang Demam Pertama. Fakultas Kedokteran Universitas Padjajaran. Sari Pediatri, 13(4): 293298.

Brouwer, M.C., Tunkel, A.R., dan van de Beek, D., 2010. Epidemiology, Diagnosis, and Antimicrobial Treatment of Acute Bacterial Meningitis. Clinical Microbiology Reviews, 23: 467492.

El Bashir, H., Laundy, M., dan Booy, R., 2003. Diagnosis and treatment of bacterial meningitis. Archives of disease in childhood, 88: 615-620. 
Fiore, A.E., Moroney, J.F., Farley, M.M., Harrison, L.H., Patterson, J.E., Jorgensen, J.H., dkk., 2000. Clinical Outcomes of Meningitis Caused by Streptococcus pneumoniae in the Era of Antibiotic Resistance. Clinical Infectious Diseases, 30: 71-77.

Goldman, J.A. dan Kearns, G.L., 2011. Fluoroquinolone Use in Paediatrics: Focus on Safety and Place in Therapy. World Health Organization, Geneva, Switzerland.

Mengistu, A., Gaeseb, J., Uaaka, G., Ndjavera, C., Kambyambya, K., Indongo, L., dkk., 2013. Antimicrobial sensitivity patterns of cerebrospinal fluid (CSF) isolates in Namibia: implications for empirical antibiotic treatment of meningitis. J Pharm Policy Pract, 6:.

Prasad, K., Kumar, A., Singhal, T., dan Gupta, P.K., 2007. Third generation cephalosporins versus conventional antibiotics for treating acute bacterial meningitis, dalam: The Cochrane Collaboration (Editor), Cochrane Database of Systematic Reviews. John Wiley \& Sons, Ltd, Chichester, UK.

Tunkel, A.R., Hartman, B.J., Kaplan, S.L., Kaufman, B.A., Roos, K.L., Scheld, W.M., dkk., 2004. Practice guidelines for the management of bacterial meningitis. Clinical infectious diseases, 39: 1267-1284. 